\title{
Allied Maritime Strategy from an Australian Perspective
}

\author{
James Goldrick
}

Australia has key interests in the effective construction and execution of allied strategy and allied maritime strategy. As they face a seemingly ever more complex security environment, both Australia and NATO must find ways of strengthening not only their capabilities for high intensity warfare but their responses to challenges at sea from a range of actors across the spectrum of conflict. Achieving this and providing effective mutual support for many shared threats will require even greater cooperation than in the past, but also some very clear thinking about key priorities and how we allocate our limited resources.

\section{Australia and Maritime Strategy}

To judge the Australian perspective on allied maritime strategy, it is critical to understand not only recent events but Australia's history since European settlement. Modern Australia is a child of the global maritime system. Its fortunes have risen and fallen alongside the fortunes of that system. Australia is at the end of the line and its livelihood depends upon the inherent efficiency of transport by sea. Long a source of primary products and natural resources and dependent on the import of manufactured goods and key materials, its remoteness has made Australia particularly sensitive to any threat to global trade and the stability of the global system. Even after the shift in recent decades from European markets to Asian ones, Australia remains the fifth largest consumer of shipping miles.

Thus, any reduction-or the prospect of such reduction-in the carrying capacity available to Australia has significant implications. It is no coincidence that each of the two world wars saw the country start - or restart - shipbuilding, purchase what merchant ships it could get and establishor re-establish-a national shipping line. Australia has also always struggled to provide for its own security. Its small population and great size mean that while Australia not only cannot guarantee the safe passage of its trade products to their ultimate destinations itself, it has also always been 
challenged just to defend its vast territories. Australia has thus long sought alignment with a great power and the surety of alliance.

That policy has had its successes and failures since the later years of the nineteenth century, when the relative decline of British global power, accompanied by the increasing militarisation of the Asia-Pacific, brought local realisation of Australia's vulnerability. It also brought a growing tension between the needs of local self-defence and support for the survival of the Empire as a whole. It became increasingly clear that what appeared vital to the Pacific periphery did not necessarily align with the judgement of the centre of the Empire. National defence was a primary impetus for Australia's federation in 1901 and a capable navy one of the first great federal projects. But the experience of the 1930s and the fall of Singapore in 1942 confirmed that Australia could become isolated and vulnerable to a regional great power if its major ally were occupied elsewhere.

The memory of Britain's strategic over-extension, and its catastrophic consequences, remains at the heart of Australia's strategic culture. It has driven its continued support of alliance with America from the start of the Cold War to the present day and contributes to many of Australia's present anxieties over the condition of the United States. What has been less well remembered is that Australia's refusal to provide a fair share of the resources needed for its own and the Empire's defence between 1919 and 1939 was as culpable as any failures by the British in that period. ${ }^{1}$

\section{The Challenges posed by China}

The rise of China has created fundamental challenges for Australia, not just because of the prospect of once again dealing with a regional great power with interests and an ideology very different to those of the West. Since European settlement, Australia's major trading and financial partners have been, if not the dominant great power then fully aligned with it. China has become Australia's primary trading partner to a degree not seen since the heyday of the British Empire when the United Kingdom fulfilled that role. Until very recently, Australia benefited greatly from its position as a reliable provider of high-quality minerals and equally high-quality

1 For a thoughtful survey of the problems that have resulted for Australia's strategic culture from its historical experience, see Michael Evans, The Third Way: Towards an Australian Maritime Strategy for the Twenty-First Century, Army Research Paper No. 1, May 2014. https://researchcentre.army.gov.au/sites/default/files/thethirdway _evans.pdf. 
agricultural products to an expanding China hungry for all it could buy. But China's increasingly strident nationalism and apparent determination to achieve at least regional hegemony at the expense of the United States, while it resets many of the conditions of the global order, mean that such a relationship sits uncomfortably alongside its security partnership with the United States. Furthermore, trade with China has itself made Australia even more vulnerable. The attraction of the huge Chinese market meant that several industries focused their export sales almost wholly in that direction. This has proved to have an element of the saying attributed to Lenin that the capitalists would sell the rope with which they will be hanged. Australia long hoped that its economic partnership with China could be managed alongside its security relationship with the United States, but it is increasingly clear that China will not accept such a modus vivendi. Since the middle of 2020, China has selectively restricted Australia's imports, focusing on those deemed non-essential to the Chinese economy but being willing to accept some domestic discomfort to punish Australia for its criticism of Chinese behaviour and its alignment with the United States.

\section{Evolving National and Maritime Strategy}

The challenges are being faced and Australia's national strategy and its maritime elements are evolving rapidly. This has been apparent since the issue of the 2009 Defence White Paper, ${ }^{2}$ which was the first official admission of the potential divergence of Chinese strategic ambitions and Australia's national interests. While the next Defence White Paper in 2013 was more moderate in its language, ${ }^{3}$ that of 2016 continued the trend. ${ }^{4}$ The latest government defence policy statement, 2020 Defence Strategic Update, was generally careful not to name China, which was mentioned only seven times and in very general terms, but was explicit that 'habits of coop-

2 Defence White Paper 2009: Defending Australia in the Twenty First Century: Force 2030, (Canberra: Department of Defence, 2009). https://www.defence.gov.au/white paper/2009/docs/defence_white_paper_2009.pdf.

3 Defence White Paper 2013, (Canberra: Department of Defence, 2013). https://www. defence.gov.au/whitepaper/2013/docs/WP_2013_web.pdf.

4 Defence White Paper 2016, (Canberra: Department of Defence, 2016). https://www. defence.gov.au/whitepaper/Docs/2016-Defence-White-Paper.pdf. 
eration in the Indo-Pacific are being challenged'. 5 The Update also rejected the idea of a decade of strategic warning time that had long been an element in defence planning. Australia's prime minister notably made comparison with the 1930s during the public launch of the document, and there were echoes here of the British decision of 1933 to abandon their own 'Ten Year Rule'. ${ }^{6}$

Although it was a defence document-Australia does not issue an overall national security statement-, the Update indicated an understanding that the nation depends upon a functioning geostrategic ecosystem and not simply on the defence of Australian territory, in continuation of the move away from the 'Defence of Australia' strategy enunciated in the 1987 Defence White Paper. ${ }^{7}$ One driver for this has been greater appreciation of the full extent of our vulnerability. In 2021, Australia remains not only tied to the global maritime system for its economic well-being, but for survival as well. It is critically dependent upon imported petroleum and, although this is less well understood, fertilisers. Australia has 'nitrogen poor' soil and must import several million tonnes a year-at least a quarter of which would be required to grow enough food just to feed its own population. The national manufacturing base, never large, has atrophied because of cheap imports. With several refineries closed because they were considered uneconomic, Australia no longer refines aviation fuel at all and must import many specialist petroleum products. It cannot be disguised that defence of the 'sea-air gap' to the north of the continent is dependent upon imported fuel that has to come by sea, a reality confirmed when a major air defence exercise was threatened by the late arrival of a tanker. ${ }^{8}$

52020 Defence Strategic Update (Canberra: Department of Defence, 2020), 2.6, 22. https://www1.defence.gov.au/strategy-policy/strategic-update-2020.

6 Scott Morrison, 'Launch of the 2020 Defence Strategic Update', 1 July 2020. https://w ww.pm.gov.au/media/address-launch-2020-defence-strategic-update.

7 The best summary of this White Paper and its concepts can be found in the Australian Parliamentary Library's research paper at: https:/www.aph.gov.au/About_P arliament/Parliamentary_Departments/Parliamentary_Library/pubs/rp/rp1516/Def endAust/1987

For earlier Australian defence policy documents between 1945 and 1976, see Stephan Frühling (ed.), A History of Australian Strategic Policy since 1945, (Canberra: Department of Defence, 2009).

8 For a study of the fuel vulnerabilities of Australia's north, see John Coyne, Tony McCormack and Hal Crichton-Standish, Running on empty? A case study of fuel security for civil and military operations at Darwin airport, Australian Strategic Policy Institute, Canberra, May 2020. https://s3-ap-southeast-2.amazonaws.com/ad-aspi/2020 -05/SR\%20154\%20Running\%20on\%20empty.pdfihVLUkU0VDfSfyFGBLARhzte mVUpoJO0. 
In fact, Australian defence policy has formally espoused a 'maritime strategy' for nearly two decades. ${ }^{9}$ Its first manifestation was the subject of a parliamentary enquiry in 2004, one which identified many of the discontinuities between the government's stated intent and its execution, at least at the start of the twenty-first century. ${ }^{10}$ What is coming into being, however, is an effort whose major components align very closely with the key elements of NATO's maritime strategy of 2011: deterrence and collective defence; crisis management; cooperative security: outreach through partnerships, dialogue and cooperation; and maritime security. These provide a useful framework for considering Australia's strategic approach overall and in the maritime domain in particular. As NATO has found with that strategy, however, what matters are how it is implemented and with what capabilities. The rise of the revisionist major powers is requiring careful reordering of Australian priorities and the allocation of greater resources than in the recent past. In the maritime domain, this parallels NATO's recent work to improve the 'Allied Maritime Posture' and its combination of deterrent effect, maritime security operations and improved warfighting capabilities.

\section{Deterrence and Collective Defence}

Australia is arming itself, albeit at a slower rate than seems appropriate, in an ever more challenging security environment. The submarine fleet will increase from six to twelve boats, a new class of frigates has been ordered, while its amphibious force will be further developed. There is a new emphasis on long range strikes and the extension of such capabilities to more platforms - sea, air and land-based. Greater efforts are being made to extend Australia's national surveillance capabilities as well as its space-based communications and reconnaissance assets. From all this, the government's intention is to possess capabilities which can have a deterrent effect, albeit in non-nuclear warfare only, and strategic weight in their own right, while also providing the potential to contribute to alliance and coalition operations in substantial ways. The most recent signal of this policy was

9 For the progress of Australian policy, starting with the 2003 Defence Update, see https://www.aph.gov.au/About_Parliament/Parliamentary_Departments/Parliame ntary_Library/pubs/rp/rp1516/DefendAust/NationalSecurity.

10 Joint Standing Committee on Foreign Affairs, Defence and Trade, Australia's Maritime Strategy, 21 June 2004. https:/www.aph.gov.au/Parliamentary_Business/Co mmittees/Joint/Completed_Inquiries/jfadt/maritime/report. 
the order for an additional two P-8A Poseidon maritime patrol aircraft to bring the Australian fleet to 14. Given that the American global force is likely to include no more than 117 aircraft, this is indicative of the growing relative importance of Australia's potential alliance contribution in many areas.

Australia is also seeking to become more resilient in ways that have important maritime aspects. Apart from the government's efforts to increase oil stockpiles and extend subsidies to the operation and modernisation of refineries, the national shipbuilding programme is seen as a key element for developing industrial and technological capabilities which will also support the sustainment and repair of Australian forces in major conflicts.

\section{Crisis Management}

It is an exaggeration to say that Australia is 'recalling the legions', but its intent to reduce the long-standing Australian effort, particularly its maritime element, in the Middle East is explicit. Frigate deployments are being wound down and the commitment of command and headquarters staff reduced or ended outright. ${ }^{11}$ This reflects a realisation that Australia must focus on its 'immediate' region, which the Strategic Update defined as 'ranging from the north-eastern Indian Ocean, through maritime and mainland South East Asia to Papua New Guinea and the South West Pacific'-an area which still represents a substantial percentage of the earth's surface. It also, critically, recognises the requirement for any national effort, both in crisis and in normal conditions, to have strategic weight. With its limited numbers and finite resources, achieving such levels of activity has never been easy for Australia, but will be vital for the country to have any chance of sending signals to China that will be heard. Semi-token deployments of individual units are being replaced by substantial task group efforts, the most notable being the annual deployments in the 'Indo-Pacific Endeavour' series. While the primary focus of each 'Indo-Pacific Endeavour' shifts between the Indian Ocean and the Western Pacific, it is no accident that almost all of them have a significant South East Asian element, including entry into the South China Sea.

11 'Australia concludes its contribution to the international Maritime Security Construct', Department of Defence, 29 December 2020. https://news.defence.gov.au/ media/media-releases/australia-concludes-its-contribution-international-maritimesecurity-construct. 


\section{Cooperative Security}

Australia's alliance with the United States remains a key element, but new partnerships with other middle powers are being sought and existing ones strengthened. Thus, defence ties with Japan have been extended, as they have with India, and all three powers have combined with the United States in the semi-formal 'Quad' alignment. Important confirmation of the way this is evolving came with Australia's inclusion in the Indian-led Exercise Malabar in November 2020. This saw the frigate HMAS Ballarat operate with an Indian naval task group and units from both Japan and the United States.

Australia is also seeking to strengthen its links, many long-standing, with the nations of maritime South East Asia. These must be managed with special care. While the states around the littorals of the South China Sea are the primary victims of China's expansionist efforts in the maritime domain, the fear of Chinese power and the economic opportunities which China offers combine to restrict responses to the challenge to their sovereign rights. Furthermore, Australia's assumption that it is a contributor to the security of the region and that its naval and air presence is wholly legitimate must now face a barrage of Chinese accusations that it is an intruder and a power external to the region-notwithstanding the reality that Darwin is considerably closer to Singapore than Shanghai is. This makes relationships such as the Five Power Defence Arrangements with Malaysia and Singapore both even more important than in the past and in need of tactful management. Such complexity is not new, given Indonesia's sensitivity to a construct devised in the early 1970 s with the recent history of confrontation in mind, but China is another problem entirely.

\section{Outreach through partnerships, dialogue and cooperation}

There are other important political and economic elements to Australia's maritime strategy. That a 'whole of nation' response will be required has been emphasised by China's use of trade as a political and economic weapon, but China's growing influence around the region has forced Australia to consider how to respond without exacerbating the situation. Not all Chinese initiatives are inherently undesirable, despite the growing tendency towards 'wolf warrior' diplomacy and a longer standing tendency towards dubious 'money politics' in the region. The reality is that Australia still seeks a secure and mutually beneficial relationship with Chi- 
na for both itself and other nation states and achieving a reasonable balance between cooperation and competition is a key aim of its policies.

Such non-military aspects are most evident in the South West Pacific, where Australia, through its 'Pacific Step-up', ${ }^{12}$ is seeking to restore its position as a partner of first choice for the Pacific Island Countries (PICs) and balance the rising influence of China. Its naval deployments are focused very much on supporting maritime security and capacity building. Australia is particularly conscious of its responsibilities in humanitarian assistance and disaster relief, activities which have been notably helpful in improving the often fractious relationship with Fiji in particular. The despatch of the large amphibious ship Adelaide to Fiji on Christmas Eve 2020 in the wake of Cyclone Yasa was almost a routine event. The government currently plans to acquire a civilian manned support vessel which will be employed to support the Australian presence in the region.

The Pacific Island Countries have benefited greatly from the inception of the Exclusive Economic Zone and the fishery resources which have come under their control. While regional management of the valuable tuna fishery has been a success story, the PICs have neither the people nor the money to manage the surveillance and response tasks unassisted. Longstanding arrangements between an older 'Quad' involving Australia, France, New Zealand and the United States are one mechanism by which resources are made available. Australia's very successful Pacific Patrol Boat programme has been another. Starting in 1983, 22 Forum class patrol boats were built and donated to 12 PICs, supported not only by robust training programmes but expert operational and technical advisers, as well as logistics and regular refits. The PICs welcomed an arrangement which gave them effective sovereign capabilities while limiting the demand on their own resources. This successful effort has been renewed in the Pacific Maritime Security Program. 19 new boats are being built for 12 PICs, with two more going to Timor-Leste. The eighth Guardian class boat to be completed was handed over to Tonga at the end of October 2020. The building programme will be completed by 2023, but Australia's aid, assisted by New Zealand, will continue indefinitely, including an in-service support centre for the Guardian class in northern Queensland. The military element of these programmes is explicitly limited. This emphasis on maritime security and law enforcement not only reflects the real needs of the PICs, but also their and Australia's desire that the region should not become an area of great power confrontation.

12 https://www.dfat.gov.au/countries/pacific-step. 
The Antarctic is another region which occupies an increasingly important place in Australian maritime strategy. The Antarctic Treaty and its associated regimes have been of considerable benefit to Australia in particular. Its extensive territorial claims have not become the subject of open contest, while the continent has remained demilitarised and nuclear free. China's increasing interest has been accepted as inevitable and the relationship between the scientific and logistic operations of both nations is generally cooperative, which was demonstrated as recently as December 2020 when Chinese assistance was critical to the medical evacuation of a sick Australian. ${ }^{13}$ Nevertheless, the scale of Chinese development on the continent - a fifth base will open in 2022 — and the noisy rhetoric about its Antarctic commitments (still much smaller than those of the US) have created uncertainty about its long-term intentions. Given that Australia's interests depend directly on the continuation of the current arrangements, the Australian government has increased its scientific commitments and provided for the replacement of a long-serving supply ship with a much larger and more capable icebreaker, Nuyina, which will begin operations in 2021.

\section{Australia and Europe in Maritime Strategy}

Australia welcomes Europe's renewed interest in the Indo-Pacific and its recognition of the unacceptable elements of China's new assertiveness. It sees NATO and Europe as important elements in its search for partners. But a combination of Australia's historical experience and a dispassionate calculation of the hard power which Europe can exert on the other side of the globe mean that there is ambivalence about what some European powers claim to be able to do, particularly those, unlike France, which no longer have significant territorial interests in the region. To give one example, the promised deployment of the new aircraft carrier Queen Elizabeth to East Asia in 2021 is certainly a welcome signal of British interest and its concerns over China's behaviour, ${ }^{14}$ but it will inherently be transient and

13 AAP 'China helps evacuate sick Australian from Antarctica in five-day mission', The Guardian, 25 December 2020. https:/www.theguardian.com/world/2020/dec/ 25/china-helps-evacuate-sick-australian-from-antarctica-in-five-day-mission.

14 Stephen Kuper, 'Rule Britannia: Royal Navy commits to Indo-Pacific carrier deployment', 15 July 2020, Defenceconnect. https://www.defenceconnect.com.au/mar itime-antisub/6458-rule-britannia-royal-navy-commits-to-indo-pacific-carrier-deplo yment. 
must come at the cost of the capacity of a severely depleted Royal Navy to manage a short-notice crisis in the European theatre.

There is also another dimension. Australia wants Europe to help reduce America's current strategic over-extension. Although acutely aware of the problematic behaviour of Putin's regime, Australia believes that China represents a greater challenge for the United States than Russia, however troublesome the latter might be, and that America should give priority to the Indo-Pacific. There is also the view that an assumption of the 'Pacific Pivot' of the Obama administration was that the European powers would assume more of the burden of deterring Russia than has proved the case by 2021. There is a tendency for the strategic establishment in Washington DC to look first across the Atlantic and there is a belief in Australia that Europe has taken advantage of this. Despite some redeployment of US forces and the stronger anti-Chinese rhetoric of the Trump administration, the full intent of the 'Pivot' has not been realised because American forces have had to maintain a greater presence in Europe than would be required if all the NATO nations were to pull their weight.

One other NATO and Pacific power deserves mention in this context: Canada. It suffers from the 'tyranny of distance' as much as Australia and not only has to look to the Atlantic but to the Arctic and the threats there of Russian claims-and Chinese meddling. Nevertheless, it will be important for Canada to continue to extend its own 'Pacific pivot', as demonstrated in its recent involvement in the sanctions programme against North Korea and ship visits around South East Asia. Even more important —and valuable-will be further increases in Canadian maritime capabilities, particularly for high intensity warfare.

In sum, Australia welcomes European powers having an active role in the Indo-Pacific and regular deployments of European naval forces in the region, but a more coherent geostrategic approach would see Europe focus - and increase-its naval and military efforts on Europe, while the United States and other Indo-Pacific powers continue to reorganise to balance China.

Put another way, Australia values the importance of the political messages sent to China by European deployments to the Indo-Pacific, particularly when they are accompanied by multinational exercises and assertions against excessive maritime claims, something both the United Kingdom 
and France have done in recent years ${ }^{15}$ and which NATO's intent for its maritime units to be able to 'operate without constraint' implies. ${ }^{16}$ Such recognition of the political value of a European presence was also made by the Japanese in recent discussions with the German minister of defence. ${ }^{17}$ This is why the German plans for deployment in 2021 are welcome, as is the promise of stronger navy to navy relations. ${ }^{18}$ But such valuation does not extend to the expectation that Europe could provide more than token support in an Indo-Pacific contingency if there were to be any possibility of a simultaneous Russian venture, such as against the Baltic states. The extent to which China and Russia are making common cause suggests that a crisis in East Asia could well be accompanied by one in Europe. ${ }^{19}$

Divisions of efforts are never wholly straightforward, and the need to maintain energy security and manage instability in the Middle East and Africa may well see continuing European operations at great distances from the European theatre. Maritime security remains a concern in the north-western Indian Ocean in particular. All these problems may also require Australian contributions in some form. But deterrence depends upon capability, and maintaining sufficient capability will depend increasingly on focused efforts, particularly in relation to high intensity operations. With limited numbers of hulls, that focus must involve some element of geographic concentration. If NATO is serious about 'Allied Maritime Posture', being strong in the Mediterranean, Baltic and Norwegian Seas, as well as in the Arctic and the Atlantic Ocean, will be challenge enough.

At the same time, Australia is aware there are many threats for which closer cooperation will be essential. These threats, notably in the cyber do-

15 Both nations contested claims in the South China Sea in 2018, most notably when HMS Albion contested Chinese claims to baselines around the Paracels. FNS Vendemaire transited the Taiwan Strait in 2019.

16 'NATO’s Maritime Activities', 20 June 2019. https:/www.nato.int/cps/en/natohq/t opics_70759.htm.

17 Julian Ryall, 'Japan calls on Germany to send warship to East Asia', DW, 18 December 2020. https:/www.dw.com/en/japan-germany-china-defense-challenges/a55985940.

18 Eryk Bagshaw and Latika Bourke, 'Germany refuses to turn a "blind eye" to China, teams up with Australia', The Sydney Morning Herald, 2 November 2020. https: //www.smh.com.au/world/asia/germany-refuses-to-turn-a-blind-eye-to-china-teams -up-with-australia-20201102-p56apf.html.

19 See Paul Dibb, How the geopolitical partnership between China and Russia threatens the West, Special Report 148, (Canberra: Australian Strategic Policy Institute, 2019). https://www.aspi.org.au/report/how-geopolitical-partnership-between-chin a-and-russia-threatens-west. 
main, may transcend geography but will have profound implications for the maritime sphere, not only in relation to state-based efforts, but across the spectrum of human activity at sea. NATO's increasing focus on improved maritime domain awareness is thus a welcome development, as are the contributions of Europe to other maritime security arrangements. ${ }^{20}$ In a way, this is only an extension of the long-standing alliance naval control and guidance of shipping framework that has worked so well and in so many regions in the past.

Australia also believes that cooperative maritime efforts in other areas will not only have benefits in their own right, but will flow on to improve the strategic environment. This is why the European Union aid efforts in the South Pacific are particularly welcome and why NATO powers, many of whom are signatories to the Antarctic Treaty, should encourage their own scientific efforts in the region and seek to be heard in the multinational fora associated with the treaty regime and its web of supporting conventions.

\section{Conclusion}

The recent initiatives by both NATO and Australia to respond to emerging strategic challenges in the maritime domain are sufficiently congruent to give reason for optimism, albeit cautious optimism. Nevertheless, their success will depend both upon the continued commitment of resources at greater levels than in the recent past, and on ensuring that our efforts are complementary in every sense. This will require sensible divisions of responsibility and, at the same time, a readiness to identify and action initiatives which can make a difference to the levels of mutual support which can be provided. All this will involve not only the cooperation of navies and maritime security authorities, but diplomats, aid agencies, business and even scientists. In the end, the successful implementation of any mar-

20 Four European nations are contracting parties to the Singapore-based Regional Cooperation Agreement on Combating Piracy and Armed Robbery against Ships in Asia (ReCAAP). See https://www.recaap.org/about_ReCAAP-ISC. 
itime strategy has both national and multinational elements across the spectrum of conflict.

\section{Works Cited}

AAP, 'China helps evacuate sick Australian from Antarctica in five-day mission', The Guardian, 25 December 2020, https://www.theguardian.com/world/2020/de c/25/china-helps-evacuate-sick-australian-from-antarctica-in-five-day-mission.

Bagshaw, Eryk and Bourke, Latika, 'Germany refuses to turn a "blind eye" to China, teams up with Australia', The Sydney Morning Herald, 2 November 2020, https:/www.smh.com.au/world/asia/germany-refuses-to-turn-a-blind-eye-to-chin a-teams-up-with-australia-20201102-p56apf.html.

Coyne, John, McCormack, Tony and Crichton-Standish, Hal, Running on empty? A case study of fuel security for civil and military operations at Darwin airport, (Canberra: Australian Strategic Policy Institute, May 2020), https://s3-ap-southeast-2.a mazonaws.com/ad-aspi/2020-05/SR\%20154\%20Running\%20on\%20empty.pdf?i hVLUkU0VDfSfyFGBLARhztemVUpoJO0.

Department of Defence, The Defence of Australia 1987, (Canberra: Australian Government Publishing Service, 1987).

Department of Defence, Defence 2000: Our Future Defence Force, (Canberra, 2000).

Department of Defence, Defence White Paper 2009: Defending Australia in the Twenty First Century: Force 2030, (Canberra, 2009), https:/www.defence.gov.au/whitepa per/2009/docs/defence_white_paper_2009.pdf.

Department of Defence, Defence White Paper 2013, (Canberra, 2013), https:/www.d efence.gov.au/whitepaper/2013/docs/WP_2013_web.pdf.

Department of Defence, Defence White Paper 2016, (Canberra, 2016), https://www.d efence.gov.au/whitepaper/Docs/2016-Defence-White-Paper.pdf.

Department of Defence, 2020 Defence Strategic Update, (Canberra, 2020), https://ww w1.defence.gov.au/strategy-policy/strategic-update-2020.

Joint Standing Committee on Foreign Affairs, Defence and Trade, Australia's Maritime Strategy, 21 June 2004, https://www.aph.gov.au/Parliamentary_Business/Co mmittees/Joint/Completed_Inquiries/jfadt/maritime/report.

Dibb, Paul, How the geopolitical partnership between China and Russia threatens the West, Special Report 148, (Canberra: Australian Strategic Policy Institute, 2019), https://www.aspi.org.au/report/how-geopolitical-partnership-between-china-andrussia-threatens-west.

Evans, Michael, The Third Way: Towards an Australian Maritime Strategy for the Twenty-First Century, Army Research Paper No. 1, May 2014, https://researchcen tre.army.gov.au/sites/default/files/thethirdway_evans.pdf.

Frühling, Stephan (ed.), A History of Australian Strategic Policy since 1945, (Canberra: Department of Defence, 2009). 
Kuper, Stephen, 'Rule Britannia: Royal Navy commits to Indo-Pacific carrier deployment', 15 July 2020, Defenceconnect, https://www.defenceconnect.com.au/m aritime-antisub/6458-rule-britannia-royal-navy-commits-to-indo-pacific-carrier-de ployment.

Library of the Parliament of the Commonwealth of Australia, 'The Defence of Australia (1987 Defence White Paper)', https://www.aph.gov.au/About_Parliament/ Parliamentary_Departments/Parliamentary_Library/pubs/rp/rp1516/DefendAus t/1987.

Library of the Parliament of the Commonwealth of Australia, 'Australia's National Security: a Defence Update 2003, 2005 and 2007’, https://www.aph.gov.au/Abou t_Parliament/Parliamentary_Departments/Parliamentary_Library/pubs/rp/rp151 6/DefendAust/NationalSecurity.

Meaney, Neville, A History of Australian Defence and Foreign Policy, 1901-23: vol. 1: The Search for Security in the Pacific, 1901-14: vol. 2: Australia and World Crisis, 1914-23, (Sydney: Sydney University Press, Sydney, 2nd edition, 2009); vol. 1 first published 1976.

Morrison, Scott, 'Launch of the 2020 Defence Strategic Update', 1 July 2020, https:// www.pm.gov.au/media/address-launch-2020-defence-strategic-update.

NATO, 'NATO’s Maritime Activities', 20 June 2019, https:/www.nato.int/cps/en/n atohq/topics_70759.htm.

Reeve, John, Maritime Strategy and the Defence of the Archipelagic Inner Arc, Working Paper No. 5, Sea Power Centre (Canberra, 2001).

Ryall, Julian, 'Japan calls on Germany to send warship to East Asia', DW, 18 December 2020, https:/www.dw.com/en/japan-germany-china-defense-challenges/ a-55985940. 